\title{
アフリカの経済開発とエネルギー資源
}

\author{
梅 津 和 郎*

\section{Economic Development and Energy \\ Resources in Africa}

\section{Kazuro UMEzU}

In this article the author deals with the possibility of combining the mineral resources with energy resources for industrial development in Africa.

As Prof. C. Bettelheim points out, the prerequisite for economic development consists in mobilizing

\section{I. 問題の所在}

発展途上地域としてのアフリカが経済開発をおしすす めていく方向について，多くの処方嘎が書かれている. そのなかには，特定国の特殊な歴史経験を模写する開発 方式もあるし，また具体的な現実を無視した抽象的なモ デル分析もある．だが，基本的には，労働生産力を引き 上げ，蓄積を可能にする工業化は不可欠であり，それな しには経済開発は不可能である。そ穴かぎりで工業化 は，あらゆる経済開発にもあてはまる一般性をもってい る.だがその工業化は，はじめからアプリオリに与えら れたものではない、 ベトウレイムも言っているように, 工業化の方式は, その国の資源賦与状態, 人口数と密度, その国の歴史的伝統などの具体的諸条件に照らして決定 される1).

アフリカの場合，第 1 表にみるように，非常に豊かな 鉱物資源に恵まれている.アフリカ諸国は，この鉱産物 を原料品として輸出しているのであるが，その佻格変動 は非常にはげしい，国連資料によって，第 1 表にふくま れた鉱産物価格の変動をみるとつぎのようである（第 2 表参照).

第 2 表は，第 1 表にかかげられた鉙産物のすべてを網 罹していないが，それでも鉣産物価格の変動程度を知る ことは可能である. その不安定性は, 経済開発に必要な 蓄積の阻害要因として作用するから，それを積極的要因 に転化することを考えねばならない。

*大阪外語大学 the existing domestic natural resources for industrialization. In this sense the abundance of the mineral and energy resources in Africa makes it possible to accelerate her economic growth if they are properly utilized.

第 1 表 アフリカ主要産鈗物の世界生産1)にし める比率 $(\%)$

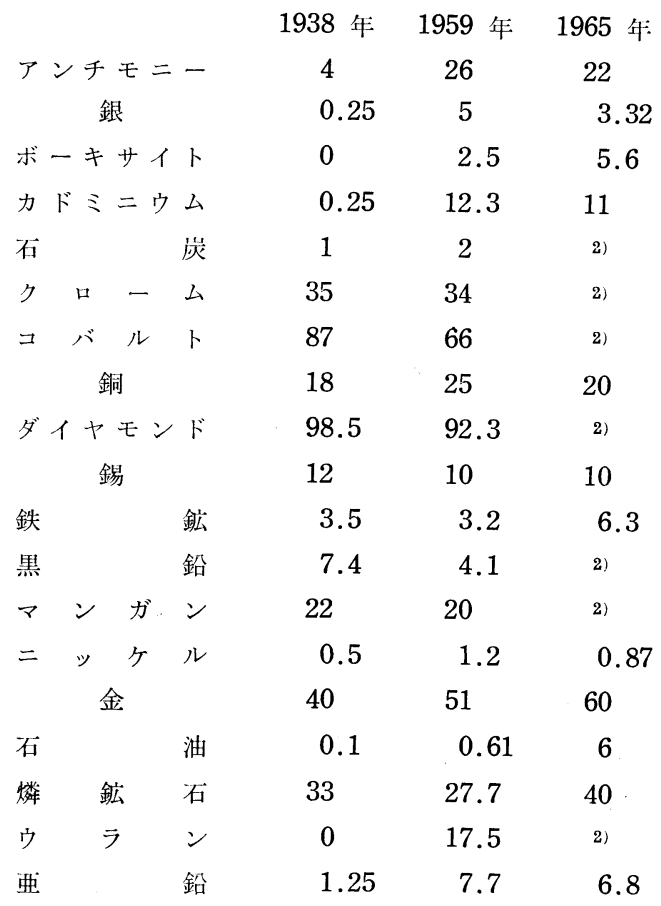

（注）「アフリカの資源」，「月刊アフリカ」，昭和 42 年 8 月号

(資料) Europe France Outremer No. 382 (1961. 9), No. 440 (1966. 9)

1) ソ連圈を除く

2) 未詳 
第 2 表 鈆産物䛧格の不安定指数 ${ }^{\mathrm{a})}$

\begin{tabular}{|c|c|c|c|}
\hline & $\begin{array}{c}1950 \text { 年代 } \\
\text { 後半b) } \\
(1)\end{array}$ & $\begin{array}{c}1960 \text { 年代 } \\
\text { 前半c) } \\
(2)\end{array}$ & $\begin{array}{c}(2) \div(1) \\
\%\end{array}$ \\
\hline マンガン鉱石 & 19.2 & 5.9 & 31 \\
\hline 鉛 (金 属) & 11.5 & 23.7 & 206 \\
\hline 亜 鉛 鉱 石 & 13.6 & 16.5 & 121 \\
\hline 銅 & 14.8 & 14.9 & 101 \\
\hline 亜 鉛（金 属） & 14.2 & 18.1 & 127 \\
\hline
\end{tabular}

a）年間変動率（変化の方向と無関係に）

b) $1953 \sim 60$ 年

c) $1960 \sim 66$ 年

(資料) The Development of an International Commodity Policy, TD/8/Supp. 1, 14 November 1967, p. 20

この豊かな鉱物資源を原料として輸出し損失を受けな がら間接的に経済開発に利用するよりも, 直接的にしか もより有効に役立てる方法はないものか、それは，ベト ウレイムの言うように，工業化なしには不可能であり， 鉙物資源を直接利用する工業化をめざすことによって解 決されねばならない。

\section{II. エネルギー資源の合理的利用}

アフリカの鉣物資源を直接利用する方法とは，現地加 工による製品利用または輸出であろら。それは，第 3 表 のように大量の動力を必要とする。言らまでもなく, 電 力は, 石油や天然ガスとことなって, 直接輸出できな い. それは, 製品加工に直接投入され, 間接輸出される かまたその国の経済開発に直接利用されたほらが，その 需要を増加しそして発電原侕を切り下げる. アフリカの 水力発電資源は, 世界の推定資源の $40 \%$ と言われてい

第 3 表 金属品加工に必要な電力

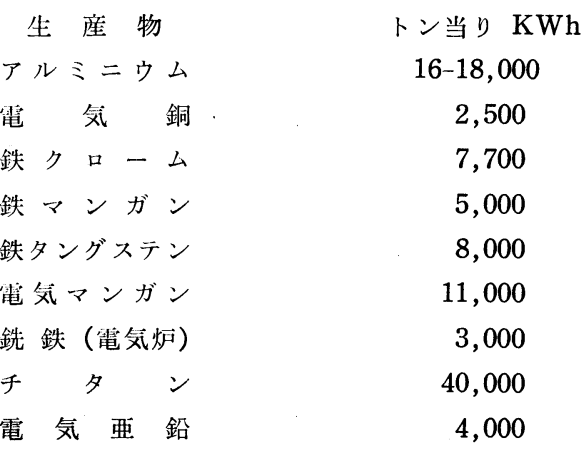

注) UN, Situation, Trends and Prospects of Electric Power Supply in Africa, 1965 , p. 3
る2). しかし，その消費量は，1961 年現在で世界の僅 か $2 \%$ 強にすぎない.ところがその増加率は，世界の それを上回まるテムポで上昇しており，1956 年ではア フリカの 1 住民当り電力消費量は世界のそれの約 $40 \%$ にすぎなかったが，61 年にはその約 70\% に增大してい る.この電力消費は, 産業需要が増加するにつれてさら にふえる見通しをもつ．たとえば，アフリカのボーキサ イト生産は, 1965 年で 190 万トンであるが，それは確 認された埋蔵量（世界の 4 分の 1 弱）の 5 ないし $6 \%$ にすぎない3). アルミニウム 1 トン生産に必要な電力 は，16,000ないし 18,000 キロワット時であるから，原 料輸出からアフリカ域内生産に転換すれば，年間約 332 億キロワット時の電力生産が必要になる. ボーキサイト 埋蔵量は現在では西アフリにかぎられているが，その年 間水力電力生産は 61 年に报いて 10 億 4,960 万キロワ ット時である4). アルミニウム生産にかぎってみても， 必要電力生産の約 $30 \%$ しか開発されていないことにな る.このように，原料輸出を国内加工に転換することに よって，それが国内および地域間のエネルギー需要を増 大させ，それが関連部門への誘発効果をもつのである.

国内加工された製品は，付加価值が多くしかもコストが 相対的に低いから，原料輸出のような不利な関係を強制 されえない.

さらにも5一つの面も考慮する必要がある.ささきにあ げた西アフリカ地域電力生産の約 $90 \%$ はカメルーンで おこなわれているが，それを利用してギニアからボーキ サイトを輸入しアルミニウムを生産する方法が採用され ている.これは，原料加工と水力電力資源とを組わせた 地域内の国際協力と考えられる。ボーキサイト鉣石の輸 送費は，ギニアとカメルーンとのあいだで海上輸送が可 能であるから，それほど大きなものではないし，力ミル ーン領内の豊富な水力電力供給がアルミニウム加工を通 じて間接的に䩱出可能となる.

発電所建設も，隣接または近接諸国間での協力を通じ てょり一層容易にそして合理的となる，たとえば，ギニ アが象牙海岸に東接した地点に発電所を建設する場合， 資材をコナクリから輸送するよりも，ライベリアのモン ロビアまたは象牙海岸から供給を受けたほうが有利であ ろう。また，建設後の電力供給は，ギニア 1 国だけでは なく，ライベリア，シェラ・レオネとして象牙海岸を対 象とすることによって，送電ロスを減少させより一層効 率的運営が可能となる。

鉱物資源の加工に水力発電を直接利用寸れば，その効 率的運営といら観点から地域的協力が必然的となるので 
ある、それは，市場の狭盒に制約された生産力の発展を 実現し，工業化の進行を可能にする.

アフリカの石油生産についても同じことが指摘され る. その生産高は, 1960 年の 1,369 万トンから 1965 年の 1 億 568 万トンと 6 年間で約 8 倍の増加となって (る5)。それは，ほとんど 6 年間に約 80 倍も石油生産 が増加したリリビアさらに約 30 倍のアルジェリア, 約 16 倍のナイジェリアに依存している。 また，ガボンは， 1961 年の 73 万トンから 67 年の 318 万トンと 5 年間 に4.3 倍に増加した6). ところが，赤道アフリカ・カメ ルーン 5 力国（チャド，中央アフリカ共和国，コンゴ・ ブラザビル, ガボン, カメルーン）の石油製品輸入は, 1961 年の 25 万 5 千トンから 67 年には 45 万 1 千ト ンと約 1.8 倍増加している. これを年率になおせば, $8.5 \%$ の増加率となる7). ガボンの石油生産は右の 5 年 間に 4.3 倍にふえながら, 石油製品輸入が 1.8 倍增加す るという奇妙な現象が生じている.このことは，アフリ カ全体についてもほぼあてはまるわけであって, 原油輸 出一一製品輸入といら仯值損失の分業が固定化されてい る. 原油産出国としてのアフリカにとって，付加価值の 高い石油製品に加工し，それを域内消費にあててさらに 輸出に充当する方法を選択するほうがより合理的であり かつ効率的なのである.

前記の赤道アフリカ・カメルーン 5 カ国の年間石油製 品消費増加率は, 自動車ガソリン, 灯油拈よび発動機用 燃料について $10 \%$ ，ガス・オイル $12 \%$ ，然料油 $20 \%$ をこえるとみなされている8 . 地域的に限定されてはい るが，このように高い消費増加率の見通しがあるにもか かわらず，たとえばガボンの原油を旧宗主国を中心とす る西欧へ輸出しているのは, 全く合理性を欠いた行動と 言える. 原油採掘と販売とを外国企業に委託し, 利権料 をせりあげていくいわゆるオペック(石油輸出国機構)方 式では，増大する国内消費需要を国内加工で充足するこ とは不可能である.ささらに，その方式は，利権料引上 げ $\rightarrow$ 原油増産によるカバー $\rightarrow$ 石油価格軟調といら悪循 環をくり返し，石油資源の無計画な浪費をもたらすにす ぎない，石油産出国が直接採掘と精製・加工をおこなっ て，付加価値の高い石油製品として域内需要を充足する 汪らが，工業化を進展させる意味でまた石油資源の浪費 を防止するらえでより合理的な方法なのである. そのた めには, アルジェリアのように, 石油採掘・精製・販売 を一貫して国家が直接担当し, 外国資本の援助は経営権 を侵害しない範囲で受けれるべきであろう。機械的かつ 排外主義的な外資受け入れ拒否は，アフリカ新興独立諸
国の開発資金不足を緩和しないし，そして最新式技術の 導入を妨げる結果となる.

前記赤道アフリカ 5 力国は, 1965 年 10 月に「赤道石 油精製会社」(S. E. R.) を設立した。 その資本は 12 億 $\mathrm{CFA}$ フランであり，全体の $25 \%$ を 5 力国が均等に出 資するが，残りの75\%は，「フランス石油会社」とイギ リスの「BP グループ」がそれぞれ半分ずつ出資した ${ }^{9)}$. この資本構成では, 国際石油資本の支配からのがれるこ とは不可能であり， 5 力国が共同で精油施設を建設する より進んだ構想も実質的には国際石油資本の利益に奉仕 する意味しかもたなくなる，石油の採掘・販売を外国私 企業に委任すると, 国内の工業化に直接寄与する石油化 学工業の建設も不可能になる. 奴隷狩りと植民地支配に よって荒廃したアフリカ農業の生産力を高めるに必要な 肥料の域内生産も，石油産業のじゅららいの方式を根本 からあらためないかぎり実現できない。

天然ガスは，一般的には結合ガス，つまり石油埋蔵地 点に原油といっしょに発見される，アフリカの天然ガス 埋蔵量は, 1 兆 8,000 億ないし 2 兆立方メートルを上 回まると推定されている(0). もちろん, それは, リビ ア，アルジェリア，ナイジェリアを中心としている．液 化天然ガスの成功によって, 天然ガスの遠距離輸送が可 能となった. リビア・天然ガスのイタリアとスペインヘ の輸出, アルジェリア・天然ガスのフランスとイギリス への輸出, さらにナイジェリア・天然ガスのイギリスと スペインへの輸出は, すべて液化施設の完成をまって実 施された。 ここでも, 石油と同じことが指摘できる.

液化天然ガスの費用構成比は, 以下のようである11).

$\begin{array}{cr}\text { 天然ガス・費用（燃料を含む） } & 18.5 \% \\ \text { 液化等費用 } & 42.5 \% \\ \text { 海上輸送費（蒸発損失分を含む） } & 39.0 \% \\ & 100.0 \%\end{array}$

上記の費用構成をみると，液化費および海上輸送費が 全体の約 $80 \%$ をしている.つまり, 天然ガス遠隔地 に輸送して利用する方式は，それ自体エネルギー源とし てまた原料としては，他により安㑣な代替ェネルギー源 または原料がある場合，非常な損夫を意味する。だか ら，天然ガスはできるだけ生産地に近い場所で工業化に 利用するほうが合理的であり，効率的なのである．この ことは, 西欧からとくに遠距離にあるナイジェリアやガ ボンについておてはまる.

天然ガスを火力発電に利用したり, また産業用がスタ 
一ビンに利用する方式は，アフリカ新興独立諸国にとっ て必要な小規模発電や動力に好適であろら.さらに, 天 然ガスを化学工業原料として利用することも可能であ る、だが問題は，その利用が国内経済開発に合理な寄与 をおこなうことであり，そのための条件整備が必要だと いうことである.

\section{III. 加速度成長におけるエネルギー資源の 位置}

発展途上国にとって加速度成長の達成は，いわば共通 項の願望となっている. その問題については実に枚挙に いとまない注り゙モデル分析がある. だがその加速度成 長の達成をたんに数量的次元に還元するのは䛊りであろ 5。発展途上国にとっては加速度成長の達成を実現する ための条件整備が先決課題であり, それを看過したとこ ろにじゅららいのモデル分析がおかした重大な誤りがあ った。

その条件整備とは，前節の行論のなかですでに部分的 に明らかになっている、つまり，それはまず，自国の経 済開発に直接貢献する行動をとらない外国資本の排除で ある. もちろん, それは, 経済開発の基幹となるエネル ギ一資源および産業の国有化であって, 企業の支配権を 掌握しない範囲の外国資本参加を受け入れることがむし ろ必要なのである。この理由も前節ですでにふれた。

条件整備の第二は, ベトゥレイムもふれているように, 国内蓄積の障害となる寄生階級の排除であろら。それ は, 二つの意味で必要である. 一つは, 寄生階級が前近 代的な社会構造を背景に政治権力を掌握して，進歩的な 改革を妨げることである. それは，国内蓄積の前提条件 創出の障害となる。 もら一つは，かれらとその門閥がお こなら寄生的消費は, 蓄積を促進するよらな需要をつく りださないことである. かれらの寄生的消費は, 大衆の 生活からかけはなれたゆがんだ需要をよびおこすだけで あり，せいぜい輸入を増加させるにすぎないからであ る.

以上の条件整備をまって経済開発の計画編成が坚施さ れなければならない, 加速度成長の実現は, 市場メ力二 ズムの「気まぐれ」に委ねるかぎり不可能である, もち ろん市場メカニズムそのものを消隇させるこはできない がエネルギー産業を含めた基幹産業の国有化のなかでそ の作用を統制し誘導することを可能である，そこに計画 実施の現実的基礎が存する.

経済開発計画の基本方式は，本稿の最初の節でふれた ように，その国の特殊条件を考察した工業化である。そ
の計画編成は，閉ざされ自給体制をめざすものではあり えないなな゙なら，とくにアフリカにおいては，人口 2,300 万といら小規模国家が多くあり，それらの国が閉 ざされた工業化を推進するならばとうてい規模の利益は 実現されえないからである。

そこで，「開かれた」工業化が必要となるのであるが， その計画編成ははじめから地域間の緊密な経済協力を含 んだものとなる．工業化をすすめていく場合，一つの地 域を構成するそれぞれの国の特殊条件を考虑した分業と 調整が当初から成立していなければならない。

1966 年の 1 月下旬から 2 月上旬にかけて，アラブ連 合のカイロに拈いて国連主催のシンポジウム「アフリカ の工業開発」が開かれた。 その報告書は，地域別の工業 開発プロジェクトをけいさいしているが，その工業化は 当初から 1 国市場の規模をこえるものとしてプロジェク トを組んである12).

その全体をここで引用するのはさけて，西アフリカの 場合のみを参考にしたい.

\section{(1) 化学品}

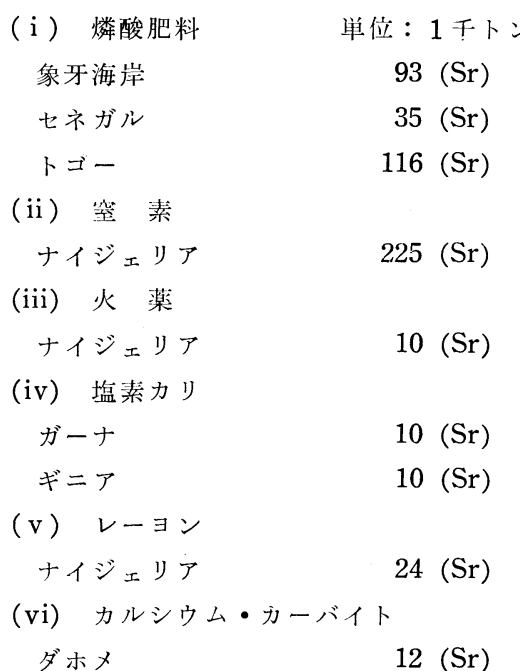

\section{（2）木材工業}

$\begin{array}{lr}\text { (i ) パルプ・製紙 } & \\ \text { ガーナ } & 60(\mathrm{Sr}) \\ \text { 象牙海岸 } & 50(\mathrm{Sr}) \\ \text { ナイジェリア } & 192(\mathrm{Sr})\end{array}$

\begin{tabular}{|c|c|}
\hline (ii) ベニア・合板 & 単位： 1 千立方米 \\
\hline ガーナ & 146 (Os) \\
\hline ギニア & 12 (Os) \\
\hline 象牙海岸 & 107 (Os) \\
\hline
\end{tabular}




$$
\begin{aligned}
& \text { ライベリア } \\
& \text { ナイジェリア } \\
& \text { セネガル }
\end{aligned}
$$

(iii) 羽目板

$$
\begin{aligned}
& \text { ガーナ } \\
& \text { 象牙海览 } \\
& \text { ナイジェリア } \\
& \text { シェラ・レオネ }
\end{aligned}
$$

\section{(3) せんい工業}

\section{（i）綿製品*}

ダホメ

ガンビア

ガーナ

ギニア

象牙海岸:

ライベリア

マリ

モーリタニア

コジェール

ナイジェリア

セネガル

シェラ・レオネ

トゴー

上部ボルタ

（4）非金属工業

(i) セメント

ダホヌ

セネガル

ガーナ

(ii) ガラス器

ガーナ
ギニア
象牙海岸
マリ
ナイジェリア
トゴー

(iii) 板ガラス

$$
\begin{aligned}
& \text { ガーナ } \\
& \text { ナイジェリア }
\end{aligned}
$$

（5）冶金工業

$$
\text { ライベリア }
$$$$
\text { マリ }
$$

ナイジェリア
16 (Os)

151 (Os)

4 (Os)

単位: 百万米ドル

$$
1.5(\mathrm{Sr})
$$

0.7 (Sr)

$1.9(\mathrm{Sr})$

0.7 (Sr)

単位: 百万平方ヤード$$
8
$$

115

15

45

5

30

2

15

280

75

30

3

6

単位：1 ケトン

$200(\mathrm{Mn})$

400 (Mn)

$60(\mathrm{Sr})$

$10(\mathrm{Mn})$

$10(\mathrm{Mn})$

$12(\mathrm{Mn})$

$5(\mathrm{Mn})$

$10(\mathrm{Mn})$

$5(\mathrm{Mn})$

$6(\mathrm{Mn})$

$10(\mathrm{Mn})$
金属製品

機械製品

電機製品

輸送設備

（注） Mn は複数国にまたがるもの

Sr は当該国が属する亜地域にまたがるも の

Os は海外市場対象のもの

* 最初は国内市場対象であるが，製品多様化 につれて亜地域対象となる

上記のプロジェクトが示すように，工業化は国内市場 问忛のものはまれであって， 汇とんど複数市場か亜地域 市場をはじめから対象としている.このような亜地域対 象の工業化が実現していくなかで, 電力, 石油, 天然ガ スを中心とするェネルギー分野の開発も地域の次元で可 能となるのである.

上記のプロジェクトはたんに工業部門別の見通しにす ぎない。しかし，引用した西アフリカについてだけで も，その不十分さは容易に指摘できる. 前節でも検討し たように，ガボンを中心とする原油生産の直接利用が不 完全であり，そのプロジェクトではいぜんとして原料輸 出一一製品輸入の分業構造を残存きせていることが判明 する，そのよらな分業構造を基本的にとどめておくかぎ り, 工業化は不可能であり加速度成長も達成されえない と私は考える.

\section{IV. 結語}

アフリカの豊富な鉣物資源とエネルギー資源とを組合 わせた工業化方式こそベトウレイムの言ら特殊条件を考 意した開発方式にほかならない。それは，じゅららいの 図式的，抽象的な開発方式へのアンチ・テーゼであり， その有効性は加速度成長の条件を整備する戦いのなかで 少しずつ証明されていくであろう。

本小論では，その有效性の定量分析は部分的であり， また亜地域規模での「開かれた」計画モデルは提示され なかった.この点を今後の課題としたい.

\section{参考 文 献}

1) Charles Bettelheim, Planification et Croissance accélérée, 1967, p. 46.

2)協会調査部「アフリカの資源」,「月刊アフリカ」, 昭和 42 年 8 月号, 14 ページ. 
3)「アフリカの資源」, 前掲誌， 12 ページ.

4) UN, Op. Cit., p. 73.

5) 協会調查部「アフリカの資源」,「月刊アフリカ」, 昭和 42 年 7 月号, 24 ページ.

6) Cameroun et Afrique équatoriale, Etudes et Statistiques, Octobre 1968, p. 535.

7) Etudes et Statistiques, Op. Cit., p. 536.
8) Etudes et Statistiques, Op. Cit., p. 536.

9) Etudes et Statistiques, Op. Cit., p. 539.

10) UN, Op. Cit., p. 17.

11) C. H. Galten, Liquefied Natural Gas-Technalo gy and Economics, 1967, p. 150.

12) UN, Report on the Symposium on Industrial Development in Africa, 1966, pp. 36-41. 